\title{
Effects of fish predation on Posidonia oceanica amphipod assemblages
}

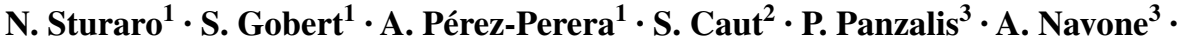 \\ G. Lepoint ${ }^{1}$
}

Received: 29 June 2015 / Accepted: 28 January 2016

(C) Springer-Verlag Berlin Heidelberg 2016

\begin{abstract}
Amphipod assemblages that inhabit Posidonia oceanica seagrass meadows are potentially relevant trophic resources for ichthyofauna. However, the effects of fish predation on amphipod assemblages in this system have received little attention. To address this gap in knowledge, experimental manipulations of predation intensity (exclusion and inclusion cages) were conducted at two sites in a Mediterranean marine protected area, where different levels of fish predation were expected to occur. We found that in the absence of predatory fishes (exclusion cages), total amphipod density and biomass were higher than in uncaged areas and partially controlled cages. At the species level, Caprella acanthifera and Iphimedia minuta responded to caging with increased abundance, while in most cases different species did not exhibit differences in density or biomass between treatments. The presence of one enclosed labrid fish predator (inclusion cages) resulted in a lower density and biomass of Aora spinicornis and a lower biomass of Phtisica marina, although total amphipod density
\end{abstract}

Responsible Editor: F. Bulleri.

Reviewed by undisclosed experts.

Electronic supplementary material The online version of this article (doi:10.1007/s00227-016-2830-1) contains supplementary material, which is available to authorized users.

N. Sturaro

nicolas.sturaro@ulg.ac.be

1 Laboratory of Oceanology, MARE Centre, University of Liege, B6C, 4000 Liege, Sart Tilman, Belgium

2 Department of Ethology and Biodiversity Conservation, Estacion Biologica Donana (CSIC), 41092 Seville, Spain

3 Marine Protected Area of Tavolara-Punta Coda Cavallo, Via Dante 1, 07026 Olbia, Italy and biomass were unchanged. In the inclusion cages, a size-frequency analysis revealed that predators mainly targeted large A. spinicornis and Apherusa chiereghinii individuals. Our results suggest that predation by fish may be an important factor in controlling amphipod abundances and biomasses in P. oceanica meadows. Overall, amphipod community composition was not affected by exclusion or inclusion of fish predators. However, some significant effects at the species level point to more complex interactions between some amphipods and fish.

\section{Introduction}

The role of predation in regulating community structure has been an important topic in ecology for many years (Hairston et al. 1960; Duffy and Hay 2001) because of its relevance in terms of basic ecological knowledge and in the management and conservation of natural systems (Valentine and Duffy 2006). Predation is one of the main factors that affect invertebrate assemblages in aquatic habitats (Shurin et al. 2002; Morin 2011) in a variety of ways. These include the direct removal of prey, which results in reductions in prey populations (Murdoch et al. 2003). However, predation can affect the morphology, physiology, and behaviour of prey populations (Sih et al. 1985; Preisser et al. 2005).

Predator-prey relationships have been well documented in a range of marine ecosystems such as soft-bottom areas, kelp forests, temperate rocky reefs, coral reefs and seagrass meadows (Pinnegar et al. 2000; Duffy and Hay 2001; Heck and Orth 2006). In seagrass ecosystems, although the role of fish predation has received considerable attention (Orth et al. 1984; Heck and Orth 2006), the frequency, importance and consequences of predation on benthic invertebrate 
assemblages are still debated. It has been demonstrated that communities associated with Zostera marina seagrass meadows can be affected by strong predation pressure that controls the biomass of mesograzers, and down the food web, of macroalgae (Moksnes et al. 2008). The available evidence is insufficient to draw any general conclusion, but the potential functional role of consumers in seagrass ecosystems may have implications for management and conservation. In meadows protected from heavy fishing (particularly in meadows within marine protected areas (MPAs), a greater abundance of some fish species may be accompanied by greater predation intensity on small fish and invertebrates (Boudouresque et al. 1992; Francour 1994, 2000). A lower abundance and species number of macroinvertebrates that are associated with rocky and seagrass ecosystems have been observed in the Scandola MPA in France (Mediterranean Sea) (Boudouresque et al. 1992), where abundance, biomass and diversity of predatory fish were greater than in adjacent, fished areas (Francour 1994, 2000).

Posidonia oceanica seagrass meadows are one of the most common and productive ecosystems in the Mediterranean coastal zone (Pergent et al. 1997; Boudouresque et al. 2006). In recent decades, P. oceanica meadows have received increasing attention in terms of conservation, which justifies their recent inclusion in MPAs and/or Sites of Community Importance (SCIs) as defined in the European Commission Habitats Directive (92/43/EEC) (Boudouresque et al. 2006; Gobert et al. 2006). P. oceanica meadows form a unique three-dimensional, spatially complex habitat, which provides a wide variety of microhabitats for benthic communities. More than 80 species of amphipod crustaceans are found in $P$. oceanica meadows (Bellan-Santini 1998) and are an important group of vagile fauna (Mazzella et al. 1989; Gambi et al. 1992; Sturaro et al. 2015). They are one of the most functionally diverse groups of crustaceans and are used for monitoring environmental effects on $P$. oceanica meadows (Sánchez-Jerez and Ramos-Esplá 1996; Sánchez-Jerez et al. 2000). From an ecological perspective, they are an important trophic resource for fish (Bell and Harmelin-Vivien 1983; Pinnegar and Polunin 2000) and play an essential role within communities associated with $P$. oceanica in terms of energy transfer from low to higher trophic levels within the food web (Scipione et al. 1996; Michel et al. 2015). Because amphipods play such an important trophic role, the possibility that the structure of amphipod assemblages could be influenced by the local level of fish predation should be investigated, particularly in the context of MPAs.

Previous studies conducted at the Tavolara-Punta Coda Cavallo Marine Protected Area (TMPA; Italy, NW Mediterranean Sea) have revealed that fish assemblages that are mainly associated with rocky reefs clearly respond to protection, with a greater abundance and size of individuals in fully protected areas (where fishing is totally banned) than in partially protected areas inside the TMPA (where fishing is allowed but regulated) and fished areas outside the TMPA (where fishing occurs simply according to national laws) (Di Franco et al. 2009; Sahyoun et al. 2013). Several amphipod taxa that are associated with $P$. oceanica meadows exhibit lower densities and/or biomasses in the fully protected areas than in the partially protected areas of the TMPA (Sturaro et al. 2014).

The aim of this study was to examine the effects of fish predation on the abundance, biomass, body size distribution and community composition of amphipod assemblages that are associated with $P$. oceanica meadows in the littoral zone of the TMPA by conducting experimental manipulations of predation intensity using exclusion and inclusion cages. We hypothesized that fish predation would (1) reduce the overall abundance and biomass of the amphipod assemblages; (2) affect the size structure of some populations by reducing the abundance of large individuals, facilitating an increased abundance of small individuals; and (3) affect the community composition of amphipod assemblages.

\section{Materials and methods}

\section{Study area}

The study was conducted in $P$. oceanica meadows in the TMPA $\left(40^{\circ} 53^{\prime} \mathrm{N}, 09^{\circ} 41^{\prime} \mathrm{E}\right)$ off north-east Sardinia (Fig. 1). The TMPA covers $15,357 \mathrm{ha}$, extends along $76 \mathrm{~km}$ of coastline and was formally established in 1997, but effective protection only started in 2003. The TMPA includes three protection zones: Zone A, integral reserves or fully protected areas (no-take/no-access zone, 529 ha); Zone $\mathrm{B}$, partial reserves or partially protected areas (3113 ha); and Zone $\mathrm{C}$, general reserves or also partially protected areas $(11,715 \mathrm{ha})$. Two sites were chosen for this study: (1) Molarotto Island in Zone A, where access is restricted to scientists, reserve personnel and police authorities; and (2) Monte Pedrosu in Zone C, where commercial and recreational fishing are allowed under restricted conditions defined by the local Consortium Management of the TMPA, with the exception of spearfishing, which is totally banned. In the study area, the rocky-reef fish assemblages were studied in detail by Di Franco et al. (2009) and Sahyoun et al. (2013). Taking these studies as reference points, Molarotto Island had the highest fish density and is hereafter referred to as the HFD (high fish density) site, while Monte Pedrosu had the lowest fish density and is hereafter referred to as the LFD (low fish density) site. Both study sites had similar depths $(8-13 \mathrm{~m})$ and $P$. oceanica meadows' structure in terms of shoot density, leaf and epiphyte biomass, and litter biomass (Sturaro et al. 2014). 


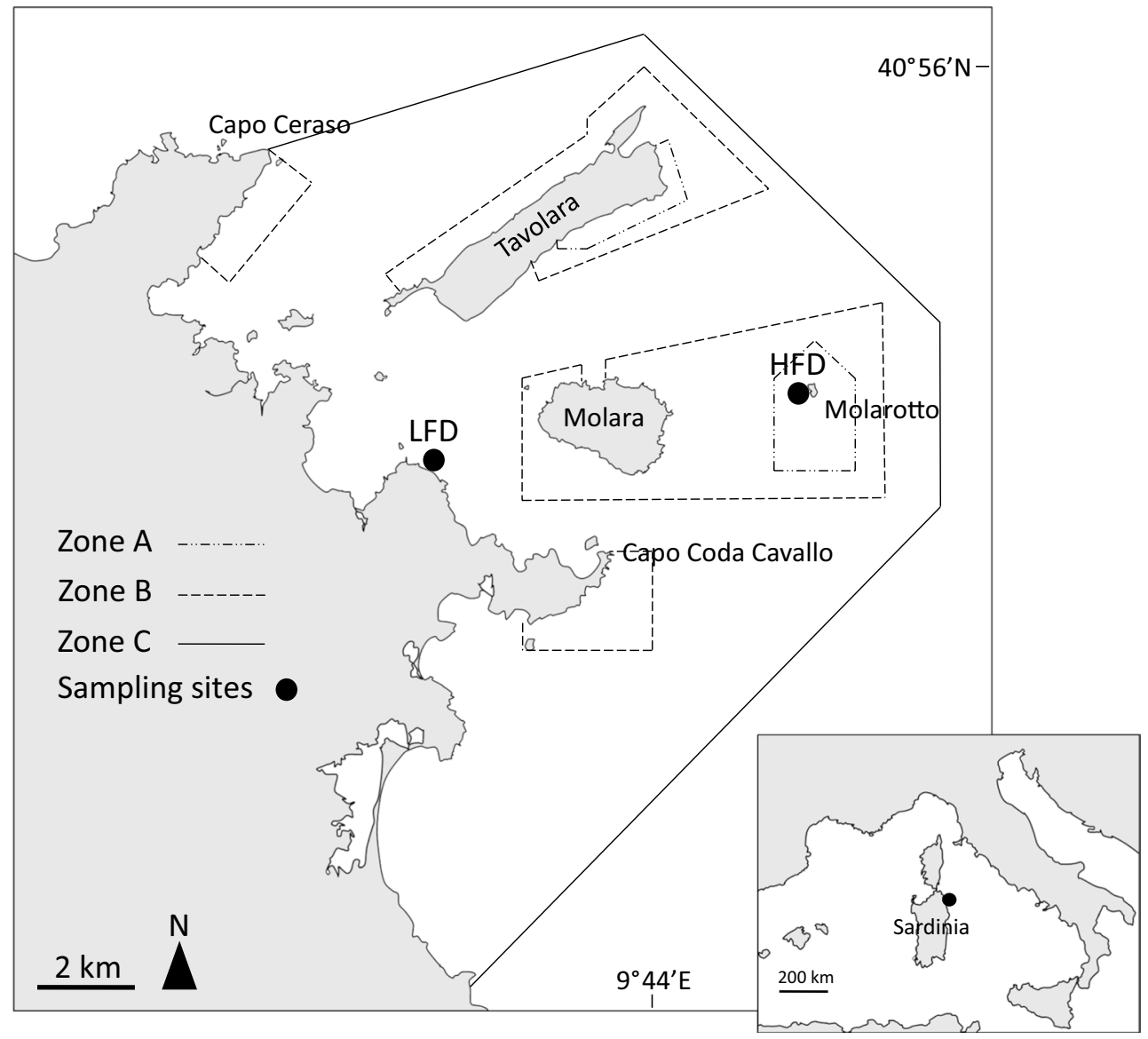

Fig. 1 Study area and location of sampling sites (HFD and LFD) at the Tavolara-Punta Coda Cavallo Marine Protected Area (Italy, Mediterranean Sea). Zone A (fully protected area), zone B and zone

\section{Characterization of HFD and LFD}

\section{Fish assemblages}

Visual censuses were performed by scuba-diving to assess fish densities along eight randomly located 20-m-long $\times 2$-m-wide transects (Harmelin-Vivien et al. 1985) at each study site for 7- to 8-min duration. All of the censuses were conducted in September 2009 between 10:00 and 13:00 (local time), in order to avoid the confounding effects of temporal variations in fish assemblages and under optimum meteorological and hydrological conditions. Fish densities were estimated by counting single specimens to a maximum of 30 individuals of each species encountered, while abundance classes (31-50, 51-100 and 101-200 individuals; see Harmelin-Vivien et al. 1985) were used for species in large groups (i.e. Chromis chromis). Densities are expressed as mean $( \pm \mathrm{SE})$ per $100 \mathrm{~m}^{2}$.

For each fish species, we attributed an amphipod index of relative importance (IRI), in order to evaluate the importance of amphipods as a food type in the diets of each fish
$\mathrm{C}$ (partially protected areas) are shown. HFD high fish density site, $L F D$ low fish density site

species, according to: $I R I=F(N+W)$. This index incorporates the percentage frequency of occurrence $(F)$, percentage number $(N)$ and percentage weight $(W)$ of amphipods to the total of all food types ingested. Values of IRI were taken from Bell and Harmelin-Vivien (1983) and Kabasakal (2001). Finally, a fish predation index (FPI) was calculated for each site: $F P I=\sum\left(N_{i} \times I R I_{i}\right) / 1000$, where $N$ is the mean number of individuals per $100 \mathrm{~m}^{2}$ and $I R I$ the amphipod index of relative importance for the $i$ th fish species. The larger the index value, the greater the fish predation was on amphipods. Note that some species (e.g. C. chromis and Diplodus annularis) had a low IRI value (i.e. low importance of amphipods in their diet), but were present in high densities and greatly influenced the FPI.

\section{Amphipod assemblages}

Amphipod samples were collected by scuba-diving using an airlift (Bussers et al. 1983; Michel et al. 2010). This was conducted at the HFD and LFD sites ( $n=5$ per site) from 28 August to 3 September 2009 between 10:00 and 18:00 
(local time) to avoid day-night variability. Sampling areas were delimited using a polyvinyl chloride cylinder (height, $48 \mathrm{~cm}$; diameter, $48.5 \mathrm{~cm}$ ) to prevent the escape of mobile species during suctioning. A surface area of $0.185 \mathrm{~m}^{2}$ was suctioned continuously for 2 min under constant airflow, and amphipods and other invertebrates were collected in a $0.5-\mathrm{mm}$-mesh bag. The samples were sieved through the $0.5-\mathrm{mm}$ mesh and fixed in a $4 \%$ formalin-seawater solution and then transferred to $70 \%$ ethanol. Amphipod densities are expressed as mean $( \pm \mathrm{SE})$ per $\mathrm{m}^{2}$.

\section{Caging experiments}

\section{Exclusion experiment}

To test the effects of fish predation on amphipod assemblage structure, predation was experimentally inhibited using cages from 30 June to 1 September 2009. This time period was chosen because of significant caging effects in most species after 8 weeks (Kennelly 1991), and it allowed enough time for several generations of amphipods to develop inside the cages (Bellan-Santini 1999; Andersson et al. 2009). Because exclusion experiments are only successful if there are significant levels of predation in the uncaged treatment for comparison (Connell 1997), only the HFD site was used. The experimental design consisted of three different treatments (uncaged areas, partially controlled cages and predator exclusion cages), which were different levels of the same factor. Five replicates of each of the three experimental treatments were included, totalling 15 experimental plots. The treatment plots were randomly distributed and 3-8 $\mathrm{m}$ apart in the P. oceanica meadows. The exclusion cages measured $75 \mathrm{~cm} \times 75 \mathrm{~cm} \times 120 \mathrm{~cm}$ and consisted of steel covered by dark green plastic mesh. A 13-mm mesh size was chosen to prevent the passage of predatory fish and to avoid major caging artefacts (i.e. light and water attenuation). Partially controlled cages were constructed from the same materials and of the same dimensions as the exclusion cages, except that only half of each wall of the cage was covered by plastic mesh. Each partially controlled cage had the structure of an exclusion cage but allowed access to predators and was used to assess the role of cage structure in altering fish assemblages. Uncaged areas were unmanipulated plots of $P$. oceanica seagrass meadow.

Amphipod samples were collected with an airlift (see "Materials and methods" above) 8 weeks after the deployment of the exclusion cages and were processed using the method described in the previous section. Amphipod density was quantified as individuals per $\mathrm{m}^{2}$, and amphipod biomass as $\mathrm{mg}$ dry weight per $\mathrm{m}^{2}$, after drying at $60^{\circ} \mathrm{C}$ for $48 \mathrm{~h}$. Both abundance and biomass were used to account for the great variability in body sizes across species.
Amphipod size (length along the dorsal side, from the distal end of the rostrum to the base of the telson) was recorded for all individuals of each species that represented more than $3 \%$ of all specimens. Measurements were taken using images obtained with a DeltaPix camera connected to a stereomicroscope (Stemi 2000, Zeiss) and the associated DpxView Pro Image Management Software (100- $\mu \mathrm{m}$ precision). The amphipod assemblage was also characterized by the total number of species $(S)$ and the ShannonWiener diversity index $\left(H^{\prime}\right): H^{\prime}=-\sum_{\mathrm{i}} p_{i} \log \left(p_{i}\right)$, where $p_{i}$ is the proportion of the total count arising from the $i$ th species. One exclusion cage was not included in the analysis because a Symphodus rostratus individual (an effective amphipod predator) entered the cage during the experiment.

The cages were scrubbed every 3-5 days to prevent algal fouling and to minimize light and water attenuation. Cage effects on water flow were tested using 48 uniform plaster blocks (method adapted from Gambi et al. 1989). These were placed inside and outside three exclusion cages ( $n=4$ inside and outside each cage), at two different locations in the canopy: above the leaves and above the base of the rhizomes. The blocks were collected $96 \mathrm{~h}$ after deployment for sufficient plaster dissolution, dried and weighed, and the percentage mass loss was recorded. Light attenuation was measured during the experiment by recording light intensity (lux) inside and outside three exclusion cages. Measurements were made, using HOBO Pendant ${ }^{\circledR}$ Temperature/Light Data Loggers every hour for 17 days, in order to account for intra- and inter-day variability. At the end of the experiment, $10 P$. oceanica shoots were collected from each treatment plot and the following plant descriptors were measured: shoot density (shoots $\mathrm{m}^{-2}$ ), leaf surface area $\left(\mathrm{cm}^{2}\right.$ shoot $\left.^{-1}\right)$, leaf and epiphyte biomass $\left(\mathrm{g} \mathrm{dw}\right.$ shoot $\left.^{-1}\right)$, and coefficient $\mathrm{A}$, which was the percentage of leaves per shoot with alteration marks (\%). Alteration marks may be indicative of either the in situ consumption of part of the plant by grazers (e.g. the fish Sarpa salpa and the sea urchin Paracentrotus lividus) or hydrodynamic action, particularly in shallow sites (Giraud 1979; Gobert et al. 2003). In each plot, leaf litter material and associated macrophyte debris (living and dead P. oceanica roots and rhizomes, and drift macroalgae) was collected in plastic bags and quantified as litter biomass $\left(\mathrm{g} \mathrm{dw} \mathrm{m}^{-2}\right)$ after drying at $60{ }^{\circ} \mathrm{C}$ for $96 \mathrm{~h}$.

\section{Inclusion experiment}

The inclusion experiment started on 29 August 2009 at the LFD site where we expected high densities of amphipods, because such an experiment is only successful if there are significant amounts of amphipod fauna available. The experimental design consisted of five replicates of uncaged areas and inclusion cages, located at random in the P. oceanica meadow and separated spatially by $3-9 \mathrm{~m}$. The 
structure and dimensions of the inclusion cages were identical to those of the exclusion cages (see above). One adult Coris julis individual (132-146 mm in length) was placed in each cage. $C$. julis is a small labrid fish that is widespread in the Mediterranean littoral zone and is affected by fishing pressure (García-Rubies and Zabala 1990). The species also lives in seagrass meadows and is a daytime feeder that preys upon small invertebrates such as molluscs, echinoderms and crustaceans; amphipods are its second main food item (14\% of the total number of food types), after molluscs (Bell and Harmelin-Vivien 1983). After 4 days of caging, C. julis individuals were sampled using a net and amphipods were sampled using the airlift sampler (see method above) in each uncaged area and inclusion cage. Amphipod processing and assemblage characterization were conducted as described in the previous section. One inclusion cage was not included in the analysis because the $C$. julis individual was not inside the inclusion cage at the end of the experiment.

\section{Statistical analyses}

An analysis of variance (ANOVA) was conducted to examine the effects of predation on (1) amphipod community metrics (total density and biomass, number of species and diversity index); (2) the density and biomass of species that each accounted for at least more than three per cent of all collected specimens in order to exclude rare species from the analysis; and (3) morphological features of $P$. oceanica in the exclusion experiment. Student $t$ tests were performed for the inclusion experiment and to test cage effects on water flow. Prior to these analyses, normality and homogeneity of variances were checked using the Kolmogorov-Smirnov and Cochran $\mathrm{C}$ tests, respectively. If these assumptions were not met, data were $\sqrt{(x+1)}$ or $\log (x+1)$ transformed. If the variances remained heterogeneous, the untransformed data were analysed, and to reduce type I errors, the significance level was set at $\leq 0.01$. In these cases, special care was taken in the interpretation of the results. To ascertain the relative magnitude of differences between the density and biomass means, we calculated effect sizes using the eta-squared value $\left(\eta^{2}\right)$. Multivariate analyses were also performed in order to test the null hypothesis of no difference in assemblage composition between treatments. We used a one-way permutational multivariate analysis of variance (PERMANOVA; Anderson et al. 2008). Similarity matrices were constructed by calculating the Bray-Curtis coefficients from square roottransformed abundance and biomass data; the data were transformed in order to account for contributions from rare species. The analyses were run with 9999 random permutations. All of the analyses were performed using STATISTICA v10, PRIMER 6 and PERMANOVA + software, and the significance level was set at 0.05 .
Table 1 Mean $\left( \pm\right.$ SE) density (number of individuals $100 \mathrm{~m}^{-2}$ ) of fishes presenting an amphipod index of relative importance (IRI from Bell and Harmelin-Vivien 1983; Kabasakal 2001), at the high fish density (HFD) site and the low fish density (LFD) site

\begin{tabular}{lrrr}
\hline & \multicolumn{2}{l}{ Density } & \multicolumn{1}{l}{ IRI } \\
\cline { 2 - 3 } & \multicolumn{1}{l}{ HFD } & \multicolumn{1}{c}{ LFD } \\
\hline Labridae & & & \\
Coris julis & $16.4 \pm 6.5$ & $23.4 \pm 7.3$ & 965 \\
Symphodus doderleini & $8.9 \pm 4.5$ & $8.4 \pm 2.5$ & 4630 \\
Symphodus mediterraneus & $1.1 \pm 0.7$ & $0.6 \pm 0.4$ & 4871 \\
Symphodus melanocercus & $0.0 \pm 0.0$ & $0.6 \pm 0.4$ & 1679 \\
Symphodus rostratus & $0.4 \pm 0.4$ & $1.3 \pm 0.7$ & 8292 \\
Symphodus tinca & $2.1 \pm 1.8$ & $0.6 \pm 0.4$ & 7480 \\
Thalassoma pavo & $1.8 \pm 0.9$ & $0.0 \pm 0.0$ & 4078 \\
Mullidae & & & \\
$\quad$ Mullus surmuletus & $0.7 \pm 0.7$ & $0.0 \pm 0.0$ & 10,561 \\
Pomacentridae & & & \\
$\quad$ Chromis chromis & $170.7 \pm 53.4$ & $34.4 \pm 9.4$ & 501 \\
Sparidae & & & \\
$\quad$ Diplodus annularis & $30.7 \pm 7.6$ & $5.6 \pm 1.5$ & 274 \\
Diplodus vulgaris & $3.2 \pm 1.3$ & $1.3 \pm 0.8$ & 2992 \\
\hline
\end{tabular}

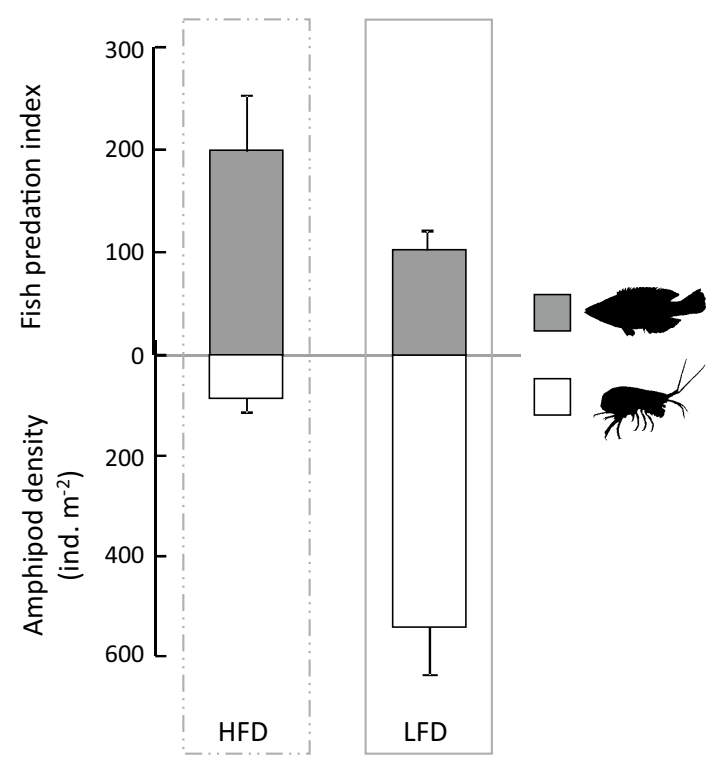

Fig. 2 Mean $( \pm$ SE) fish predation index $(F P I)$ and total amphipod density (number of individuals $\mathrm{m}^{-2}$ ) between the high fish density (HFD) site and the low fish density (LFD) site at the Tavolara-Punta Coda Cavallo Marine Protected Area

\section{Results}

\section{Characterization of HFD and LFD}

We recorded 18 fish species at the two sampling sites. The more speciose families were Labridae ( 8 species) and 
Table 2 Mean $( \pm \mathrm{SE})$ density of Posidonia oceanica (shoots $\left.\mathrm{m}^{-2}\right)$, leaf surface area $\left(\mathrm{cm}^{2}\right.$ shoot $\left.^{-1}\right)$, leaf and epiphyte biomass $\left(\mathrm{g} \mathrm{dw}\right.$ shoot $\left.^{-1}\right)$, litter biomass $\left(\mathrm{g} \mathrm{dw} \mathrm{m}^{-2}\right)$ and coefficient A (\%) between uncaged areas, partial control cages and exclusion cages in the exclusion experiment

\begin{tabular}{lcccc}
\hline & Uncaged & Partial control & Exclusion & $p$ \\
\hline Shoot density & $491.5 \pm 17.9$ & $534.8 \pm 61.4$ & $546.7 \pm 47.7$ & 0.680 \\
Leaf surface area & $311.03 \pm 12.46$ & $317.91 \pm 13.34$ & $298.41 \pm 11.19$ & 0.852 \\
Leaf biomass & $1.72 \pm 0.17$ & $1.74 \pm 0.17$ & $1.51 \pm 0.09$ & 0.846 \\
Epiphyte biomass & $0.08 \pm 0.03$ & $0.07 \pm 0.01$ & $0.08 \pm 0.03$ & 0.465 \\
Litter biomass & $39.55 \pm 12.52$ & $29.69 \pm 7.22$ & $19.97 \pm 4.56$ & 0.321 \\
Coefficient A & $38.75 \pm 1.36$ & $27.06 \pm 1.63$ & $28.18 \pm 1.52$ & $\underline{0.002}$ \\
\hline
\end{tabular}

Results of ANOVA between the treatments: significance level is reported and underlined when $P \leq 0.05$
Sparidae (5 species). Based on the amphipod IRI values of each fish, 11 species were considered to have a predation impact on amphipods (10 species in HFD and 9 species in LFD, Table 1). The density of these fishes was 3.1 times higher at HFD $\left(236.1 \pm 62.4\right.$ ind. $\left.100 \mathrm{~m}^{-2}\right)$ than in LFD $\left(76.3 \pm 16.4\right.$ ind. $\left.100 \mathrm{~m}^{-2}\right)$, while the FPI was 1.9 times higher at the HFD site than in the LFD site (Fig. 2).

We found 471 amphipod individuals belonging to 24 species. The total amphipod density was 6.3 times higher at the LFD site $\left(543.5 \pm 83.6\right.$ ind. $\left.{ }^{-2}\right)$ than in the HFD site $\left(86.6 \pm 24.5\right.$ ind.m ${ }^{-2} ;$ Fig. 2$)$. At the species level, A. chiereghinii $\left(2.2 \pm 1.3\right.$ ind. $\mathrm{m}^{-2}$ in the HFD site and $202.4 \pm 31.4$ ind. $\mathrm{m}^{-2}$ in the LFD site), A. spinicornis (17.3 \pm 3.2 ind. $\mathrm{m}^{-2}$ in the HFD site and $127.7 \pm 25.3$ ind. ${ }^{-2}$ in the LFD site) and Phtisica marina $\left(1.1 \pm 1.1\right.$ ind. $\mathrm{m}^{-2}$ in the HFD site and $36.8 \pm 11.3$ ind. $\mathrm{m}^{-2}$ in the LFD site) explained a great part of the observed total amphipod density difference.

\section{Caging experiments}

\section{Exclusion experiment}

There was a significant effect of caging on water motion, as differences in mass loss in plaster blocks placed inside exclusion cages $(54.3 \pm 0.3 \%)$ and in bare $P$. oceanica plots $(63.3 \pm 0.5 \%)$ show $(P<0.001)$. No differences were observed inside the leaf stratum (inside cages $38.8 \pm 0.8 \%$ and outside cages $41.5 \pm 0.9 \%$ ). For the effects of cages on light attenuation, we observed a decrease of luminous intensity within the cage of $26.2 \pm 1.5 \%$. Regarding the effects of cages on the meadow's features, no differences were observed between uncaged areas, partial control cages and exclusion cages for shoot density, leaf surface area, leaf and epiphyte biomass, and litter biomass, except for coefficient A $(P=0.002$; Table 2$)$.

A total of 331 amphipod individuals belonging to 15 families and 20 amphipod species were identified. For all samples, the assemblage was dominated by A. spinicornis (14.2\% of the total number of individuals), C. tavolarensis $(9.7 \%)$ and Iphimedia minuta $(9.1 \%)$. Total amphipod density $(P=0.003)$ and biomass $(P=0.023$, Fig. 3 , ESM 1) were significantly different between exclusion cages
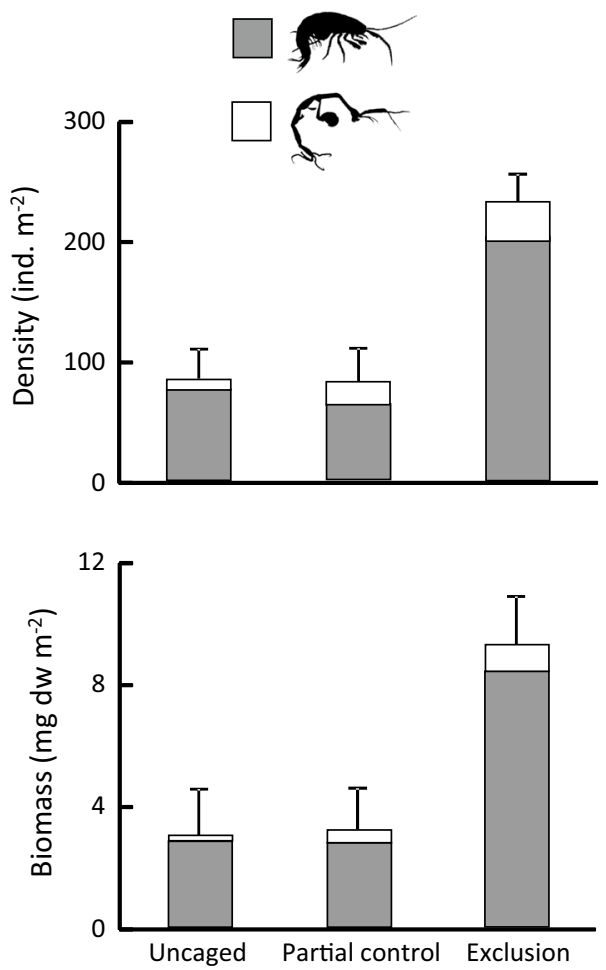

Fig. 3 Mean $\left( \pm \mathrm{SE}\right.$ ) density (number of individuals $\mathrm{m}^{-2}$ ) and

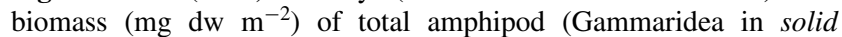
bars + Caprellidea in open bars) between uncaged areas, partial control cages and exclusion cages

and partial control cages/uncaged areas after 8 weeks. At the suborder level, Gammaridea density and biomass were higher in exclusion cages relative to uncaged areas and partial control cages $(P=0.012$ and $P=0.042$, respectively). Caprellidea, however, showed a higher biomass in exclusion cages $(P=0.020)$ and no differences for density $(P=0.141$; ESM 1$)$. At the species level, fish exclusion had a significant effect on the density $(P=0.001)$ and biomass $(P=0.018)$ of Caprella acanthifera and on the density of $I$. minuta $(P=0.028$; ESM 1$)$. These two species had the largest effect sizes for density and biomass, which were greater than Orchomene humilis and Hyale camptonyx. Apolochus neapolitanus, Aora spinicornis and Caprella tavolarensis had the smallest effect sizes (Fig. 4). 


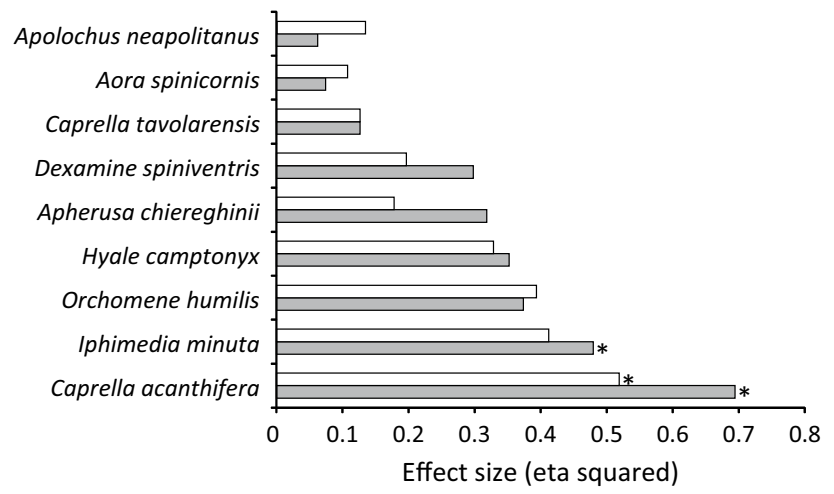

Fig. 4 Effect sizes (reported as eta-squared; $\eta^{2}$ ) of fish predation effects on different amphipod species in the exclusion experiment. Density in solid bars and biomass in open bars. An asterisk indicate a significant effect of the respective species based on $P \leq 0.05$
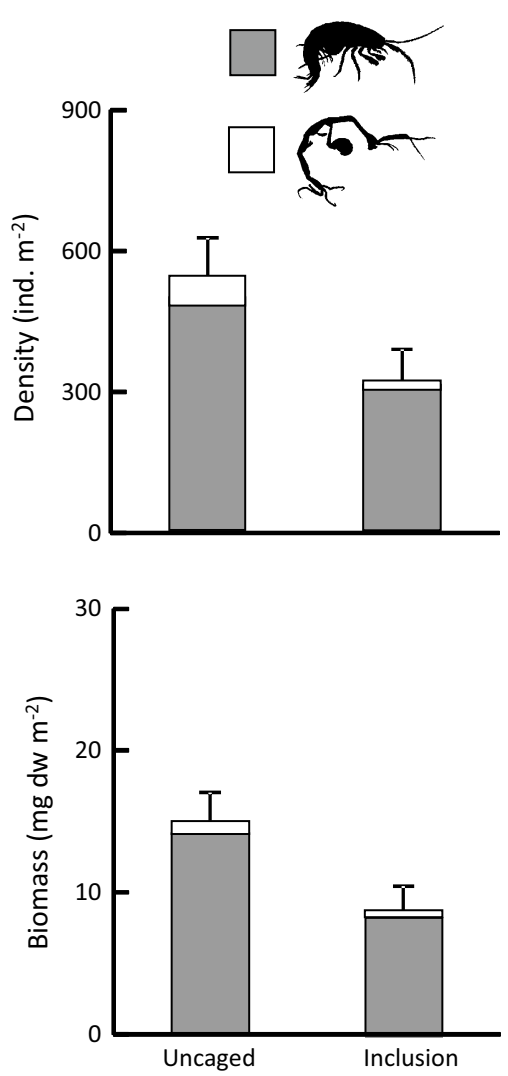

Fig. 5 Mean $( \pm \mathrm{SE})$ density (number of individuals $\mathrm{m}^{-2}$ ) and biomass $\left(\mathrm{mg} \mathrm{dw} \mathrm{m}^{-2}\right.$ ) of total amphipod (Gammaridea in solid bars + Caprellidea in open bars) between uncaged areas and inclusion cages

A significant difference was observed between treatments for the number of species $(S=5.8 \pm 1.4$ in uncaged area, $S=5.2 \pm 1.3$ in partial control cage, $S=10.5 \pm 1.3$ in exclusion cage; $P=0.044)$, but no significant differences were observed for the diversity index $\left(H^{\prime}=1.49 \pm 0.27\right.$

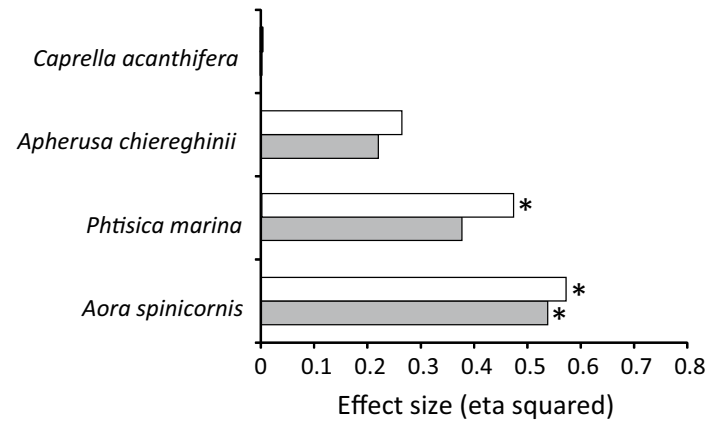

Fig. 6 Effect sizes (reported as eta-squared; $\eta^{2}$ ) of fish predation effects on different amphipod species in the inclusion experiment. Density in solid bars and biomass in open bars. An asterisk indicate a significant effect of the respective species based on $P \leq 0.05$

in uncaged area, $H^{\prime}=1.30 \pm 0.35$ in partial control cage, $H^{\prime}=2.08 \pm 0.13$ in exclusion cage, $P=0.191$ ). There were no significant changes in the community composition between exclusion cages, partial control cages and uncaged areas for abundance (PERMANOVA, Pseudo-F $=1.58$, $P=0.146$ ) and biomass (PERMANOVA, Pseudo-F $=1.00$, $P=0.420$ ). Size-frequency distribution of amphipod species was unimodal and did not show any pattern between exclusion cages, partial control cages and uncaged areas.

\section{Inclusion experiment}

A total of 741 individuals belonging to 14 families and 24 amphipod species were identified. For all samples, the assemblage was dominated by A. chiereghinii (39.4\% of the total number of individuals), A. spinicornis (20\%) and $P$. marina $(5.5 \%)$. The total amphipod density did not show significant differences between inclusion cages and uncaged areas, but the total biomass was marginally significant $(P=0.051$ for biomass; Fig. 5, ESM 2$)$. At the species level, $A$. spinicornis density $(P=0.024)$ and biomass $(P=0.018)$ and $P$. marina biomass $(P=0.041)$ were significantly lower within inclusion cages (ESM 2). These two species had the largest effect sizes for density and biomass, which were greater than A. chiereghinii. For $C$. acanthifera, the effect size was very small (Fig. 6). Uncaged areas and inclusion cages exhibited no significant differences for the number of species $(S=9.3 \pm 1.0$ and $S=9.2 \pm 0.8$, respectively) and diversity index $\left(H^{\prime}=1.45 \pm 0.07\right.$ and $H^{\prime}=1.45 \pm 0.05$, respectively). There were no significant changes in the community composition between uncaged areas and inclusion cages, in terms of abundance (PERMANOVA, Pseudo-F $=1.83, P=0.057$ ) and biomass (PERMANOVA, Pseudo-F $=0.45, P=0.602$ ). A sizefrequency analysis was carried for the two most abundant species separately (i.e. A. spinicornis and A. chiereghinii). This analysis revealed that fish inclusion mainly affected 


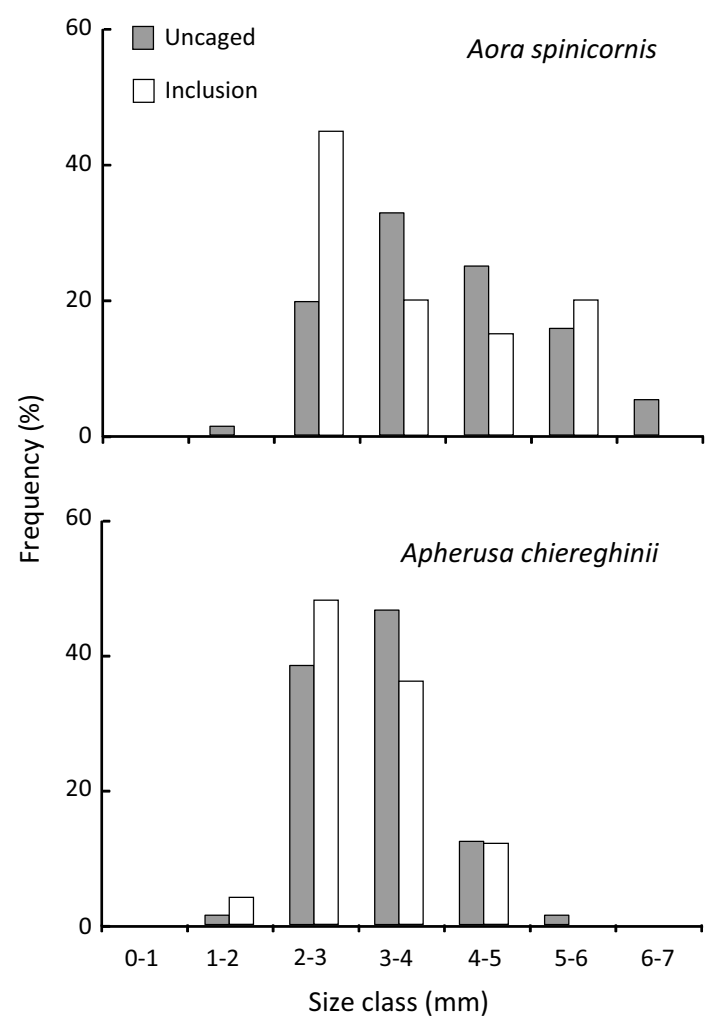

Fig. 7 Proportional size-frequency distributions of Aora spinicornis ( $n=76$ in uncaged areas and 20 in cages) and Apherusa chiereghinii ( $n=73$ in uncaged areas and 50 in cages) in the inclusion experiment

larger individuals, with an inversion of the first mode represented by individuals of 3-4 mm by amphipods of $2-3 \mathrm{~mm}$ in size. The larger individuals of A. spinicornis $(6-7 \mathrm{~mm})$ and $A$. chiereghinii $(5-6 \mathrm{~mm})$ were only present within the uncaged treatment (Fig. 7).

\section{Discussion}

We found that the densities of amphipods and fishes that are associated with $P$. oceanica meadows were significantly different between sites of high and low fish predation. The high densities of many fish species that we observed at the high fish predation site confirm the results of previous studies in the area (Di Franco et al. 2009; Sahyoun et al. 2013). These studies showed that in the sublittoral rocky habitats of the TMPA, fish (including amphipod feeders such as Sciaena umbra and Diplodus vulgaris) biomass and/or density is up to three times greater inside fully protected areas than in partially protected areas. In $P$. oceanica meadows, several authors have reported that large piscivorous and invertebrate-feeding fishes are generally present in greater abundance and diversity in fully protected areas than in partially protected and unprotected areas (Francour 2000; Macpherson et al. 2002; Valle and Bayle-Sempere 2009). The lower densities of several amphipod taxa that are associated with $P$. oceanica meadows in the fully protected areas relative to the partially protected areas of the TMPA (Sturaro et al. 2014), may have been associated with a higher fish predation intensity. This is consistent with the results of previous studies that suggest that the spatial distribution of amphipod abundance is associated with seagrasses and may be regulated by fish predation (Nelson 1979; Caine 1991; Moksnes et al. 2008).

The exclusion experiments revealed that total amphipod density and biomass, as well as the number of species, are positively affected by the exclusion of fish. These results are in accordance with previous studies, which showed that amphipod densities and the number of species increase in areas in which fish are excluded (Kennelly 1991; Sala 1997; Moksnes et al. 2008). It has also been suggested that fish predation may determine seasonal changes in the number of amphipod species and diversity by selectively removing certain species (Nelson 1979). In our study, amphipods exhibited species-specific patterns in response to fish exclusion, which could have been related to their different life history strategies and ecological behaviour. Prey species' vulnerability to predation depends on their detectability and ease of capture (Paloheimo 1979), which in turn depends on their morphology (e.g. pigmentation and body structure), behaviour and microhabitat distribution (Stein 1977). Our results suggest that the caprellid $C$. acanthifera suffers from fish predation more than other amphipod species, probably because caprellids are exposed on the surfaces and tips of leaves (Virnstein et al. 1984) and are usually associated with epiphytes (Aoki 1999). They are important prey items for many coastal fishes (Caine 1989, 1991; Woods 2009). C. acanthifera can grow to a large size $(13 \mathrm{~mm})$ and moves over the substratum with an inchworm-like movement (Guerra-García et al. 2002), which probably makes it more easily detectable by a predator than other, smaller caprellids such as $C$. tavolarensis $(2-6 \mathrm{~mm}$ ) (Sturaro and Guerra-García 2012). Similarly, the large species Caprella dilatata is probably more easily detected by the labrid Thalassoma pavo than are the smaller caprellids, Caprella hirsuta and Caprella grandimana, which live on seaweed (Vázquez-Luis et al. 2010). Gammarid density is also affected by predation, particularly that of I. minuta, which is a prey item of $P$. oceanica fishes (Labropoulou and Plaitis 1995). Despite their motility, their habit of hiding between seagrass blades (Virnstein et al. 1984) and/or their use of strategies such as burrowing and infaunal tube-dwelling, gammarids are one of the most abundant food items for P. oceanica fishes (Zupo and Stübing 2010). At the HFD site, the relative availability of gammarid prey was much higher (89\%) than that of caprellid prey (11\%). This may affect the 
probability of them encountering a predator and thus influence their susceptibility to predation.

Consistent with the results of exclusion experiment, the results of the inclusion cages also indicated predation effects. The enclosed labrid fish $C$. julis caused a lower density and biomass of the gammarid A. spinicornis, and a lower biomass of the caprellid P. marina. These two amphipod species were abundant at the LFD site (where fish predation intensity was lower), and together accounted for more than $30 \%$ of the total number of amphipods found, with almost 280 individuals per $\mathrm{m}^{2}$ in some areas. P. marina is found on both the sediment and blades in seagrass meadows (González et al. 2008) and attaches to the substrate in an "upright" position (Guerra-García et al. 2002), suggesting that this species can be easily detected by predators. Many caging studies have shown that invertebrate densities are lower when predators are present (e.g. Edgar 1990; Kennelly 1991; Sala 1997). Surprisingly, the abundance of $C$. acanthifera and A. chiereghinii did not differ between treatments; the former responded to fish predation in the exclusion experiment, and the latter is one of the principal prey species of $P$. oceanica fishes (Labropoulou and Plaitis 1995). Furthermore, based on density and biomass data, no direct effect of either treatment on the composition of amphipod assemblages was demonstrated, but surveys conducted in the TMPA indicate a difference between the totally protected and partially protected areas. Numerous hypotheses have been proposed by authors to explain the lack of significant predator effects. Our results may be a consequence of the presence of refugia and adaptations for predator avoidance and are therefore scaledependent (Englund and Olsson 1996; Englund 1997).

Although the fish $C$. julis is not an amphipod-feeding specialist (i.e. medium IRI; Bell and Harmelin-Vivien 1983), this species has reached high densities in the area and has one of the greater FPI. Nevertheless, the inclusion treatment resulted in a decrease in the number of large $A$. spinicornis and $A$. chiereghinii individuals, suggesting that this species preferentially consumes large individuals of these species. Several studies in the marine environment have focused on the mechanisms involved in prey selection by predatory fishes (Nelson 1979, 1981; Clements and Livingston 1984; Main 1985). It has been suggested that the predator's choice is primarily determined by prey size, but also by prey motion (Main 1985) and pigmentation (Clements and Livingston 1984). Fish predation that causes a shift towards small amphipod individuals and/or species appears to be common in marine ecosystems (Edgar and Aoki 1993; Moksnes et al. 2008). In a Z. marina seagrass meadow using a caged goby predator, Moksnes et al. (2008) showed that size-specific predation reduced the abundance of adult gammarids by $93 \%$, whereas juvenile abundance was unaffected. However, experiments in which predatory fish are enclosed have been criticized, because it is unclear whether their results reflect truly natural conditions. In our study, the enclosed density (equivalent to one fish per $0.56 \mathrm{~m}^{2}$ ) was higher than that seen in nature. Moreover, the contrived conditions under which predatory fish are enclosed may alter their behaviour and generate unreal effects (Hindell et al. 2000).

However, caging experiments remain a valuable tool in predation studies of seagrass meadows (Edgar 1990; Hindell et al. 2001; Moksnes et al. 2008) and other marine ecosystems (Connell 1997; Sala 1997; Langlois et al. 2006). It is difficult to eliminate the possibility that any effects that were detected were due to caging artefacts. However, potential problems may be minimized or alleviated through careful planning, evaluation of the potential artefacts and cautious interpretation (Kennelly 1991; Steele 1996; Connell 1997). In our study, major artefacts, such as the low water current velocity inside the cages, did not appear to be important within the $P$. oceanica canopy. This may have been due to the periodic cage cleaning that prevented the build-up of fouling (Sala and Boudouresque 1997) and phenological features of the Posidonia canopy that play an important role in reducing water movement (Gambi et al. 1989). Light attenuation was moderate inside the cages, and no differences were detected between the treatments after eight weeks in any of the biotic features of $P$. oceanica measured, except for the percentage of leaves having alteration marks. This may have been caused by greater herbivore grazing pressure in uncaged areas (e.g. by the fish Sarpa salpa). We can therefore assume that cage effects on amphipod biomass and abundance were little compared to the effect of predator exclusion or presence.

Despite the careful attention given to the design and the set-up of the cages, as well as the necessary procedures that were taken to avoid caging artefacts, the two experiments (exclusion and inclusion cages) only included a small number of replicates (i.e. five replicates per experimental treatment, totalling 14 and 9 experimental plots, respectively, due to the loss of a plot from each experiment). The absence of any significant difference between the treatments for some of the variables examined could have been due to the low number of replications, and only large differences could have been detected. Analysis of the relative effect sizes demonstrated that some species (e.g. O. humilis) might also be affected by predation. Future studies aimed at examining predation effects on macrofaunal assemblages in $P$. oceanica meadows should include more than five replicates, in order to ensure that there is sufficient variability in all of the variables measured. The study could also have been improved if the exclusion and inclusion cages had been placed in both the HFD and LFD sites.

In conclusion, this study provides experimental evidence that fish predation in $P$. oceanica meadows depresses the 
overall abundance and biomass of amphipod assemblages. It also reduces the density and biomass of certain amphipod species and in some cases alters the size structure. However, the community composition of amphipod assemblages was not affected. These results suggest that the densities of fishes that are associated with $P$. oceanica meadows were significantly different between sites of high and low fish predation. Therefore, this may contribute to the difference in amphipod abundance and biomass (but not in community composition) that has been observed between the fully protected and partially protected areas of the TMPA (Sturaro et al. 2014). The patterns observed at the species and community levels suggest that complex interactions are involved, which could be related to the behaviour of amphipod and fish species. Further investigation is required to improve our understanding of predator avoidance and predator strategies in this ecosystem. Manipulative experiments should be conducted in order to test how the density and diversity of fish predators (e.g. generalist versus specialized amphipod feeders) influence the abundance and biomass of amphipod assemblages.

Acknowledgments The authors would like to thank R. Biondo for technical assistance in the development of the caging devices (Laboratoire d'Océanologie, Université de Liège, Belgium), S. Vitale for technical assistance during field work (Consorzio di Gestione Area Marina Protetta Tavolara-Punta Coda Cavallo, Olbia, Italy) and all volunteers for field and laboratory assistance. We would like to thank P. Guidetti, S. Vermeulen and anonymous referees for their critical comments which greatly improved the manuscript. This study was supported by the Belgian Fund for Research for the Industry and Agriculture (FRIA, grant nr. FC77010), by a Special Research Fund of the University of Liege (FSR) and by the Belgian National Fund for Scientific Research (FNRS). This paper is MARE publication number 321 .

\section{References}

Anderson MJ, Gorley RN, Clarke KR (2008) PERMANOVA + for PRIMER: guide to software and statistical methods. PRIMER-E, Plymouth

Andersson S, Persson M, Moksnes PO, Baden S (2009) The role of the amphipod Gammarus locusta as a grazer on macroalgae in Swedish seagrass meadows. Mar Biol 156:969-981

Aoki M (1999) Morphological characteristics of young, maternal care behaviour and microhabitat use by caprellid amphipods. J Mar Biol Assoc UK 79:629-638

Bell JD, Harmelin-Vivien ML (1983) Fish fauna of French Mediterranean Posidonia oceanica seagrass meadows. 2. Feeding habits. Tethys 11:1-14

Bellan-Santini D (1998) Ecology. In: Ruffo S (ed) The Amphipoda of the Mediterranean, Part 4. Mémoires de l'Institut océanographique no. 13, Monaco, pp 869-893

Bellan-Santini D (1999). Ordre des Amphipodes (Amphipoda Latreille, 1816). In: Forest $\mathrm{J}$ et al. (eds) Traité de zoologie: anatomie, systématique, biologie: 7. Crustacés: 3A. Péracarides. Mémoires de l'Institut océanographique no. 19, Monaco, pp 93-176
Boudouresque CF, Caltagirone A, Lefevre JR, Rico V, Semroud R (1992) Macrozoobenthos de la réserve naturelle de Scandola (Corse, Méditerranée nord-occidentale). Analyse pluriannuelle de « l'effet réserve ». In: Olivier J, Gérardin N, Jeudy de Grissac A (eds) Impact économique des espaces côtiers protégés de Méditerranée. MedPAN News 3, Ajaccio, pp 15-20

Boudouresque CF, Bernard G, Bonhomme P, Charbonnel E, Diviacco G, Meinesz A, Pergent G, Pergent-Martini C, Ruitton S, Tunesi L (2006) Préservation et conservation des herbiers à Posidonia oceanica. Ramoge Publication, Monaco

Bussers JC, Poulicek M, Diepvints J (1983) Description d'une suceuse à air comprimé économique et utilisable par un seul plongeur. Cah Biol Mar 24:215-217

Caine EA (1989) Caprellid amphipod behavior and predatory strikes by fish. J Exp Mar Biol Ecol 126:173-180

Caine EA (1991) Caprellid amphipods: fast food for the reproductively active. J Exp Mar Biol Ecol 148:27-33

Clements WH, Livingston RJ (1984) Prey selectivity of the fringed filefish, Monacanthus ciliatus (Pisces: Monacanthidae): role of prey accessibility. Mar Ecol Prog Ser 16:291-295

Connell SD (1997) Exclusion of predatory fish on a coral reef: The anticipation, pre-emption and evaluation of some caging artefacts. J Exp Mar Biol Ecol 213:181-198

Di Franco A, Bussotti S, Navone A, Panzalis P, Guidetti P (2009) Evaluating effects of total and partial restrictions to fishing on Mediterranean rocky-reef fish assemblages. Mar Ecol Prog Ser 387:275-285

Duffy JE, Hay ME (2001) Ecology and evolution of marine consumer-prey interactions. In: Bertness M, Hay ME, Gaines SD (eds) Marine community ecology. Sinauer Press, Sunderland, pp 131-157

Edgar GJ (1990) Predator-prey interactions in seagrass beds. III. Impacts of the western rock lobster Panulirus Cygnus George on epifaunal gastropod populations. J Exp Mar Biol Ecol 139:33-42

Edgar GJ, Aoki M (1993) Resource limitation and fish predation: their importance to mobile epifauna associated with Japanese Sargassum. Oecologia 95:122-133

Englund G (1997) Importance of spatial scale and prey movements in predator caging experiments. Ecology 78:2316-2325

Englund G, Olsson T (1996) Treatment effects in a stream fish enclosure experiment: influence of predation rate and prey movements. Oikos 77:519-528

Francour P (1994) Pluriannual analysis of the reserve effect on ichthyofauna in the Scandola natural reserve (Corsica, Northwestern Mediterranean). Oceanol Acta 17:309-317

Francour P (2000) Evolution spatio-temporelle à long terme des peuplements de poissons des herbiers à Posidonia oceanica de la réserve naturelle de Scandola (Corse, Méditerranée Nord-Occidentale). Cybium 24:85-95

Gambi MC, Buia MC, Casola E, Scardi M (1989) Estimates of water movement in Posidonia oceanica beds: a first approach. In: Boudouresque CF, Meinesz CF, Fresi E, Gravez V (eds) International workshop on Posidonia beds. GIS Posidonie, France, pp $101-112$

Gambi MC, Lorenti M, Russo GF, Scipione MB, Zupo V (1992) Depth and seasonal distribution of some groups of the vagile fauna of the Posidonia oceanica leaf stratum: structural and trophic analyses. Mar Ecol 13:17-39

García-Rubies A, Zabala M (1990) Effects of total fishing prohibition on the rocky fish assemblages of Medes Islands marine reserve (NW Mediterranean). Sci Mar 54:317-328

Giraud G (1979) Sur une méthode de mesure et de comptage des structures foliaires de Posidonia oceanica (Linnaeus) Delile. Bull Mus Hist Nat Marseille 39:33-39 
Gobert S, Kyramarios M, Lepoint G, Pergent-Martini C, Bouquegneau JM (2003) Variations at different spatial scales of Posidonia oceanica (L) Delile beds; effects on the physico-chemical parameters of the sediment. Oceanol Acta 26:199-207

Gobert S, Cambridge ML, Velimirov B, Pergent G, Lepoint G, Bouquegneau JM, Dauby P, Pergent-Martini C, Walker DI (2006) Biology of Posidonia. In: Larkum AWD, Orth RJ, Duarte CM (eds) Seagrasses: biology, ecology and conservation. Springer, Dordrecht, pp 387-408

González AR, Guerra-García JM, Maestre MJ, Ruiz-Tabares A, Espinosa F, Gordillo I, Sánchez-Moyano JE, García-Gómez JC (2008) Community structure of caprellids (Crustacea: Amphipoda: Caprellidae) on seagrasses from southern Spain. Helgol Mar Res 62:189-199

Guerra-García JM, Corzo J, García-Gómez JC (2002) Clinging behaviour of the Caprellidea (Amphipoda) from the Strait of Gibraltar. Crustaceana 75:41-50

Hairston NG, Smith FE, Slobodkin LB (1960) Community structure, population control and competition. Am Nat 94:421-425

Harmelin-Vivien ML, Harmelin JG, Chauvet C, Duval C, Galzin R, Lejeune P, Barnabe G, Blanc F, Chevalier R, Duclerc J, Lasserre G (1985) Evaluation visuelle des peuplements et populations de poissons: problèmes et méthodes. Rev Ecol (Terre Vie) 40:467-539

Heck KL Jr, Orth RJ (2006) Predation in seagrass beds. In: Larkum AWD, Orth RJ, Duarte CM (eds) Seagrasses: biology, ecology and conservation. Springer, Dordrecht, pp 537-550

Hindell JS, Jenkins GP, Keough MJ (2000) Evaluating the impact of predation by fish on the assemblage structure of fishes associated with seagrass (Heterozostera tasmanica) (Martens ex Ascherson) den Hartog, and unvegetated sand habitats. J Exp Mar Biol Ecol 255:153-174

Hindell JS, Jenkins GP, Keough MJ (2001) Spatial and temporal variability in the effects of fish predation on macrofauna in relation to habitat complexity and cage effects. Mar Ecol Prog Ser 224:231-250

Kabasakal H (2001) Description of the feeding morphology and the food habits of four sympatric labrids (Perciformes, Labridae) from South-Eastern Aegean Sea, Turkey. Neth J Zool $51: 439-455$

Kennelly SJ (1991) Caging experiments to examine the effects of fishes on understorey species in a sublittoral kelp community. J Exp Mar Biol Ecol 147:207-230

Labropoulou M, Plaitis W (1995) Selective predation on small crustaceans by six demersal fish species in Iraklion Bay (Cretan Sea, North-eastern Mediterranean). In: Eleftheriou A, Ansell AD, Smith CJ (eds) Biology and ecology of shallow coastal waters: proceedings of the 28th European marine biology symposium. IMBC, Iraklio, pp 351-357

Langlois TJ, Anderson MJ, Babcock RC, Kato S (2006) Marine reserves demonstrate trophic interactions across habitats. Oecologia 147:134-140

Macpherson E, Gordoa A, Garcia-Rubies A (2002) Biomass size spectra in littoral fishes in protected and unprotected areas in the NW Mediterranean. Est Coast Shelf Sci 55:777-788

Main KL (1985) The influence of prey identity and size on selection of prey by two marine fishes. J Exp Mar Biol Ecol 88:145-152

Mazzella L, Scipione MB, Buia MC (1989) Spatio-temporal distribution of algal and animal communities in a Posidonia oceanica meadow. PSZN Mar Ecol 10:107-129

Michel L, Lepoint G, Dauby P, Sturaro N (2010) Sampling methods for amphipods of Posidonia oceanica meadows: a comparative study. Crustaceana 83:39-47

Michel LN, Dauby P, Gobert S, Graeve M, Nyssen F, Thelen N, Lepoint G (2015) Dominant amphipods of Posidonia oceanica seagrass meadows display considerable trophic diversity. Mar Ecol 36:969-981

Moksnes P-O, Gullström M, Tryman K, Baden S (2008) Trophic cascades in a temperate seagrass community. Oikos 117:763-777

Morin PJ (2011) Predation and communities: empirical patterns. In: Morin PJ (ed) Community ecology, 2nd edn. Wiley Blackwell, Oxford, pp 90-119

Murdoch W, Briggs C, Nisbet R (2003) Consumer-resource dynamics. Princeton University Press, Princeton

Nelson WG (1979) Experimental studies of selective predation on amphipods: consequences for amphipod distribution and abundance. J Exp Mar Biol Ecol 38:225-245

Nelson WG (1981) Experimental studies of decapod and fish predation on seagrass macrobenthos. Mar Ecol Prog Ser 5:141-149

Orth RJ, Heck KL, Van Montfrans J (1984) Faunal communities in seagrass beds: a review of the influence of plant structure and prey characteristics on predator-prey relationships. Estuaries $7: 339-350$

Paloheimo JE (1979) Indices of food type preference by a predator. J Fish Res Bd Can 36:470-473

Pergent G, Rico-Raimondino V, Pergent-Martini C (1997) Fate of primary production in Posidonia oceanica meadows of the Mediterranean. Aquat Bot 59:307-321

Pinnegar JK, Polunin NVC (2000) Contributions of stable-isotope data to elucidating food webs of Mediterranean rocky littoral fishes. Oecologia 122:399-409

Pinnegar JK, Polunin NVC, Francour P, Badalamenti F, Chemello R, Harmelin-Vivien ML, Heureu B, Milazzo M, Zabala M, D'Anna G, Piptone C (2000) Trophic cascades in benthic marine ecosystems: lessons for fisheries and protected area management. Environ Conserv 27:179-200

Preisser EL, Bolnick DI, Benard MF (2005) Scared to death? The effect of intimidation and consumption in predator-prey interactions. Ecology 86:501-509

Sahyoun R, Bussotti S, Di Franco A, Navone A, Panzalis P, Guidetti P (2013) Protection effects on Mediterranean fish assemblages associated with different rocky habitats. J Mar Biol Assoc UK 93:425-435

Sala E (1997) The role of fishes in the organization of a Mediterranean sublittoral community. II: epifaunal communities. J Exp Mar Biol Ecol 212:45-60

Sala E, Boudouresque CF (1997) The role of fishes in the organization of a Mediterranean sublittoral community. I: algal assemblages. J Exp Mar Biol Ecol 212:25-44

Sánchez-Jerez P, Ramos-Esplá AA (1996) Detection of environmental impacts by bottom trawling on Posidonia oceanica (L) Delile meadows: sensitivity of fish and macroinvertebrate communities. J Aquat Ecosyst Health 5:239-253

Sánchez-Jerez P, Barberá-Cebrian C, Ramos-Esplá AA (2000) Influence of the structure of Posidonia oceanica meadows modified by bottom trawling on crustacean assemblages: comparison of amphipods and decapods. Sci Mar 64:319-326

Scipione MB, Gambi MC, Lorenti M, Russo GF, Zupo V (1996) Vagile fauna of the leaf stratum of Posidonia oceanica and Cymodocea nodosa in the Mediterranean Sea. In: Kuo J, Phillips RC, Walker DI, Kirkman H (eds) Seagrass biology: proceedings on an international workshop. Rottnest Island, Western Australia, pp 249-260

Shurin JB, Borer ET, Seabloom EW, Anderson K, Blanchette CA, Broitman BR, Cooper SD, Halpern BS (2002) A cross-ecosystem comparison of the strength of trophic cascades. Ecol Lett 5:785-791

Sih A, Crowley P, McPeek M, Petranka J, Strohmeier (1985) Predation, competition and prey communities: a review of field experiments. Annu Rev Ecol Syst 16:269-311 
Steele MA (1996) Effects of predators on reef fishes: separating cage artefacts from effects of predation. J Exp Mar Biol Ecol 198:249-267

Stein RA (1977) Selective predation, optimal foraging, and the predator-prey interaction between fish and crayfish. Ecology 58:1237-1253

Sturaro N, Guerra-García JM (2012) A new species of Caprella (Crustacea: Amphipoda) from the Mediterranean Sea. Helgol Mar Res 66:33-42

Sturaro N, Lepoint G, Pérez-Perera A, Vermeulen A, Panzalis P, Navone A, Gobert S (2014) Seagrass amphipod assemblages in a Mediterranean marine protected area: a multiscale approach. Mar Ecol Prog Ser 506:175-192

Sturaro N, Lepoint G, Vermeulen S, Gobert S (2015) Multiscale variability of amphipod assemblages in Posidonia oceanica meadows. J Sea Res 95:258-271

Valentine JF, Duffy JE (2006) The central role of grazing in seagrass ecology. In: Larkum AW, Orth RJ, Duarte CM (eds) Seagrasses: biology, ecology and conservation. Springer, Netherlands, pp 463-501
Valle C, Bayle-Sempere JT (2009) Effects of a marine protected area on fish assemblages associated with Posidonia oceanica seagrass beds: temporal and depth variations. J Appl Ichthyol 25:537-544

Vázquez-Luis M, Sanchez-Jerez P, Bayle-Sempere JT (2010) Effects of Caulerpa racemosa var. cylindracea on prey availability: an experimental approach to predation of amphipods by Thalassoma pavo (Labridae). Hydrobiologia 654:147-154

Virnstein R, Nelson W, Lewis F, Howard R (1984) Latitudinal patterns in seagrass epifauna: do patterns exist, and can they be explained? Estuaries 7:310-330

Woods C (2009) Caprellid amphipods: an overlooked marine finfish aquaculture resource? Aquac 289:199-211

Zupo V, Stübing D (2010) Diet of fish populations in Posidonia oceanica meadows off the Island of Ischia (Gulf of Naples, Italy): assessment of spatial and seasonal variability. Nat Sci 2:1274-1286 